\title{
Laura Doan, Disturbing Practices History, Sexuality and Women's Experience of Modern War
}

Florence Binard

\section{(2) OpenEdition}

12 Journals

Electronic version

URL: http://journals.openedition.org/rfcb/315

DOI: $10.4000 / \mathrm{rfcb} .315$

ISSN: 2429-4373

Publisher

CRECIB - Centre de recherche et d'études en civilisation britannique

Printed version

Date of publication: 15 January 2015

ISSN: 0248-9015

\section{Electronic reference}

Florence Binard, «Laura Doan, Disturbing Practices History, Sexuality and Women's Experience of Modern War », Revue Française de Civilisation Britannique [Online], XX-1 | 2015, Online since 01 May 2015, connection on 22 September 2020. URL : http://journals.openedition.org/rfcb/315; DOI : https://doi.org/10.4000/rfcb.315

This text was automatically generated on 22 September 2020 .

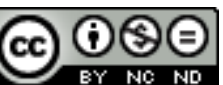

Revue française de civilisation britannique est mis à disposition selon les termes de la licence Creative Commons Attribution - Pas d'Utilisation Commerciale - Pas de Modification 4.0 International. 


\title{
Laura Doan, Disturbing Practices History, Sexuality and Women's Experience of Modern War
}

\author{
Florence Binard
}

\section{REFERENCES}

Laura Doan, Disturbing Practices History, Sexuality and Women's Experience of Modern War, Chicago and London, University of Chicago Press, 2013, 278p.

1 Laura Doan is professor of cultural history and sexuality studies at the University of Manchester (UK). She is the author of Fashioning Sapphism: The Origins of a Modern English Lesbian Culture (2001).

2 Her latest monograph, Disturbing Practices is a thought provoking innovative book that takes us well beyond the central focus presented in the subtitle: History, Sexuality, and Women's Experience of Modern War. At the same time a history book and a book on the making of history Disturbing Practices revisits the received impact of the Great War on the emergence of lesbianism in Britain whilst opening new paths on how the past can be historicised.

3 Initially conceived along a similar framework to her previous writings, Doan explains that Disturbing Practices "changed as a result of the peculiarities and conceptual roadblocks [she] encountered in the archive" (p. 5). Disturbing Practices marks a turning point in her theoretical stance regarding her contributions to the making of history in that she proposes a shift from the genealogical approach, which so far had largely characterised her work, to what she calls « a queer critical history ».

4 The title, "Disturbing Practices » is a play on words which applies to the two sections that the book is divided into: the theoretical part and the applied or practicing part. On the one hand, the purpose is both to unsettle the practices of historians of sexuality by reconsidering the theories and methods on which they rely in their research work and 
to put forward what she presents as « a queer critical history » combining queer theory and critical history in order to " construct how the sexual was known, partially known, and not known " (p.198). On the other hand, Disturbing Practices proposes to show by way of example how to apply a "queer critical history" methodology to the disturbing practices of some notorious nurses during WWI, thus disturbing research on disturbing practices both past and present.

Building on her impressive theoretical knowledge, Doan discusses the purpose of the history of sexuality, she describes and analyses the methods used to historicise the lives of individuals identified as belonging to the LGBT category.

Referring to the work of Michael Oakeshott who established a distinction between the historical past (knowing about the past for its own sake) and the practical past (knowing about the past as a tool for the present) (p.9) she posits the fact that most historians of sexuality trace back the past from a present-day framework which relies on modern identity categories that did not exist in the past reality studied. And she draws conclusions on the values and pitfalls of ancestral lesbian/gay and queer genealogies, the difference between the two lying in the fact that ancestral genealogy consists of the recovery work that makes visible " gay /lesbian » individuals or group of individuals who were/are still absent from History whereas queer genealogy aims to trace back « queer subjects » beyond the homo/hetero binary.

7 If Doan concurs with Joan Scott and agrees that «the facts of history " never "speak for themselves » (p.49), her contention is that the past was/is "messier" than is often thought to be and certainly "messier" than historians would like it to have been. Her personal experience of the discovery of this "messiness" drove her to investigate the possibility of "embark(ing) with an unknowingness about the past to discover what is now "unheard of" (p.4).

8 From the point of view of the history of sexuality, the choice of the Great War is an obvious one since both social historians and historians of sexuality regard this moment as crucial in the emergence of « lesbian » subcultures.

Indeed, because the war brought about changes in gender roles - out of necessity, since for war purposes women were performing jobs that so far had only been occupied by men, they were wearing clothes and uniforms that "masculinised" them, and were enjoying a form of independence that would have been impossible before the war - it seems coherent, from a genealogical stance, to establish a link between the war conditions and a nascent form of lesbianism.

However, as underlined by Doan, this genealogical approach, which relies on a modern identity category (LGBT), leaves out "beings who [came] into existence as the result of transitory conditions of war, with no equivalences and therefore untranslatable" ( $p$. 132).

11 Doan's "queer" subjects thus present great historical interest because they are not situated inside our modern parameters but more importantly because they lie outside of these parameters, because they did not view themselves as sexual subjects.

Doan shows that, during the war, the apparent "muscular femininity" of many women did not raise negative feelings that, on the contrary, they often raised admiration. Her research also indicates that ordinary people did not generally name or self-name regarding sexual matters (p.139), that therefore, for the vast majority, gender variance or sexual variance were not linked to identities, that most people simply did not label 
these phenomena because they did not perceive them constitutive of a personal identity.

13 At the core of Disturbing Practices lies the question of "Sexual identity as a process" ( $p$. 139), the exploration of the shift which led to the understanding that "doing something immoral" meant "being something immoral" that is to say "a Sapphist" (p.154).

In the preface to Disturbing Practices, Laura Doan declares :

What vexes me now about my earlier account of a nascent lesbian subculture in modern Britain is that - from the very start - I believed I knew more about female sexuality in the 1920s than the individuals I was researching; equally troubling was my inattentiveness to the purpose of my history writing. (p.xi)

This courageous personal statement testifies to Laura Doan's intellectual honesty but, perhaps of even greater import, it shakes up our own too often unquestioned beliefs and practices. Disturbing Practices invites us to ponder on our own research and to reflect on the purposes of our own writings thus engaging us to revisit our practices and reminding us that what seems obvious, what is taken for granted, often hides a far more complex and « messier » reality.

Rather than proposing a new theory that would supersede an earlier one, the queer critical theory put forward by Laura Doan aims at adding a different approach to existing theories and practices so that they may mutually enrich each other. Indeed, whilst acknowledging the value of disciplinarity, Doan shows that disciplines are often too limiting (p.53).

17 To sum up, Disturbing Practices is both intellectually challenging and inspiring. It shows, through a theoretical discussion combined with a concrete application of the theory, how queer theory linked with critical theory may open up new ways of making history not just in the field of the history of sexuality but beyond, onto the wider discipline of « academic history ».

\section{AUTHORS}

\section{FLORENCE BINARD}

Université Paris Diderot 